\author{
O.V. Sukhova
}

\title{
The Effect of Carbon Content and Cooling Rate on the Structure of Boron-rich $\mathrm{Fe}-\mathrm{B}-\mathrm{C}$ alloys
}

\author{
The Oles' Honchar Dniprovs 'k National University, Dnipro,Ukraine, sukhovaya@ukr.net
}

\begin{abstract}
The structural and phase composition of boron-rich $\mathrm{Fe}-\mathrm{B}-\mathrm{C}$ alloys in the concentration range of $9.0-16.0 \%$ $\mathrm{B}, 0.001-1.7 \% \mathrm{C}, \mathrm{Fe}$ - the balance (in wt. \%) was investigated in this work. The cooling rate of the alloys was from 10 to $10^{3} \mathrm{~K} / \mathrm{s}$. The methods of quantitative metallographic, X-ray, energy dispersive X-ray, and differential thermal analyses were applied. It was established that the maximal solubility of carbon in $\mathrm{Fe}_{2} \mathrm{~B}$ hemiboride does not exceed $0.55 \%$, and that in FeB monoboride - $0.41 \%$. The alloys that belong to two-phase peritectic $\left(\mathrm{Fe}_{2}(\mathrm{~B}, \mathrm{C})+\mathrm{Fe}(\mathrm{B}, \mathrm{C})\right)$ region, two-phase peritectic-eutectic $\left(\mathrm{Fe}_{2}(\mathrm{~B}, \mathrm{C})+\mathrm{Fe}(\mathrm{B}, \mathrm{C})\right)$ region, and three-phase peritectic-eutectic $\left(\mathrm{Fe}_{2}(\mathrm{~B}, \mathrm{C})+\mathrm{Fe}(\mathrm{B}, \mathrm{C})+\mathrm{C}\right)$ region of the $\mathrm{Fe}-\mathrm{B}-\mathrm{C}$ phase diagram were distinguished depending on their structure. The appearance of an eutectic constituents in the investigated alloys was explained by transition of peritectic reaction $\mathrm{L}+\mathrm{Fe}(\mathrm{B}, \mathrm{C}) \rightarrow \mathrm{Fe}_{2}(\mathrm{~B}, \mathrm{C})$ to eutectic reaction $\mathrm{L} \rightarrow \mathrm{Fe}(\mathrm{B}, \mathrm{C})+\mathrm{Fe}_{2}(\mathrm{~B}, \mathrm{C})$ within the temperature range of $1623-1583 \mathrm{~K}$ in the presence of carbon. With cooling rate increasing from 10 to $10^{3} \mathrm{~K} / \mathrm{s}$, structural constituents tended to be fine, their volume fraction changed, microhardness and fracture toughness increased.
\end{abstract}

Key words: structure, cooling rate, crystallization, phase transformations, microdurometric characteristics.

Received 05 February 2020; Accepted 15 June 2020.

\section{Introduction}

$\mathrm{Fe}-\mathrm{B}$ alloys have attracted lots of interest because they exhibit high hardness, wear resistance, oxidation and heat resistance [1-4]. In addition, these alloys require low processing cost [5]. This combination of properties may be utilized in a variety of applications like wear and corrosion resistant coatings [6-8]. However, there are still discrepancies concerning the phase and structural composition of $\mathrm{Fe}-\mathrm{B}$ alloys in concentration range from 9 to 16 wt.\% of boron. Thus, authors [9] and many other thought that these alloys had peritectic structure consisted of primary $\mathrm{FeB}$ crystals and $\mathrm{Fe}_{2} \mathrm{~B}$ phase formed by peritectic reaction $\mathrm{L}+\mathrm{FeB} \rightarrow \mathrm{Fe}_{2} \mathrm{~B}$. Authors [10] reported that $\mathrm{Fe}_{2} \mathrm{~B}-\mathrm{FeB}$ eutectic might exist in the structure of $\mathrm{Fe}-\mathrm{B}$ alloys. They claimed that $\mathrm{FeB}$ phase was not observed in the structure of $\mathrm{Fe}-9 \% \mathrm{~B}$ alloy after quenching from melt. Therefore, they concluded that $\mathrm{Fe}_{2} \mathrm{~B}$ did not form through peritectic, but through eutectic reaction.

The described discrepancies concerning structural composition of $\mathrm{Fe}-\mathrm{B}$ alloys may be attributed to the effect of additions, in the first place, carbon, on the structure formation of $\mathrm{Fe}-\mathrm{B}$ alloys [11]. Iron metal is very reactive with respect to carbon. During specimen preparation this component may easily absorb from the air and, therefore, it may be considered as natural addition to $\mathrm{Fe}-\mathrm{B}$ alloys. The phase composition of $\mathrm{Fe}-\mathrm{B}-\mathrm{C}$ alloys in concentration range of $9-16 \mathrm{wt}$. \% of $\mathrm{B}$ was described in [12,13]. Authors [13] considered carbon solubility of about 2 at. $\%$ in the iron borides and distinguished three three-phase equilibrium regions in the phase diagram, namely: $\left(\mathrm{FeB}+\mathrm{Fe}_{2} \mathrm{~B}+\mathrm{C}\right)$, $\left(\mathrm{B}+\mathrm{FeB}+\mathrm{B}_{4} \mathrm{C}\right),\left(\mathrm{B}_{4} \mathrm{C}+\mathrm{FeB}+\mathrm{C}\right)$. But authors [13] did not suggest possible reactions involving the revealed phases which might be responsible for structure formation of the alloys, and authors [12] did not proved the expected reactions experimentally.

Better understanding of the solidification microstructure of $\mathrm{Fe}-\mathrm{B}-\mathrm{C}$ alloy system with cooling rate is essential to support the utilization of the alloys in which a wide range of cooling rates might be encountered during metallurgical processing including 
The effect of carbon on phase and structural composition of $\mathrm{Fe}-\mathrm{B}-\mathrm{C}$ alloys

\begin{tabular}{|c|c|c|c|}
\hline $\begin{array}{c}\text { Carbon content } \\
\text { (in wt. \%) }\end{array}$ & Structure & Phase composition & Structural composition \\
\hline $0.01-0.165$ & Two-phase peritectic & $\mathrm{Fe}_{2}(\mathrm{~B}, \mathrm{C}), \mathrm{Fe}(\mathrm{B}, \mathrm{C})$ & $\mathrm{Fe}_{2}(\mathrm{~B}, \mathrm{C}), \mathrm{Fe}(\mathrm{B}, \mathrm{C})$ \\
\hline $0.17-0.5$ & $\begin{array}{c}\text { Two-phase peritectic- } \\
\text { eutectic }\end{array}$ & $\mathrm{Fe}_{2}(\mathrm{~B}, \mathrm{C}), \mathrm{Fe}(\mathrm{B}, \mathrm{C})$ & $\begin{array}{c}\mathrm{Fe}_{2}(\mathrm{~B}, \mathrm{C}), \mathrm{Fe}(\mathrm{B}, \mathrm{C}), \\
\mathrm{Fe}_{2}(\mathrm{~B}, \mathrm{C})-\mathrm{Fe}(\mathrm{B}, \mathrm{C}) \text { eutectic }\end{array}$ \\
\hline $0.55-1.7$ & $\begin{array}{c}\text { Three-phase peritectic- } \\
\text { eutectic }\end{array}$ & $\begin{array}{c}\mathrm{Fe}_{2}(\mathrm{~B}, \mathrm{C}), \mathrm{Fe}(\mathrm{B}, \mathrm{C}), \\
\mathrm{Ce}\end{array}$ & $\begin{array}{c}\mathrm{Fe}_{2}(\mathrm{~B}, \mathrm{C}), \mathrm{Fe}(\mathrm{B}, \mathrm{C}), \mathrm{C} \text { globules, } \\
\mathrm{Fe}_{2}(\mathrm{~B}, \mathrm{C})-\mathrm{C} \text { colonies, } \\
\mathrm{Fe}_{2}(\mathrm{~B}, \mathrm{C})-\mathrm{Fe}(\mathrm{B}, \mathrm{C})-\mathrm{C} \text { eutectic }\end{array}$ \\
\hline
\end{tabular}

Table 2

The effect of carbon content (in wt. \%) and cooling rate on crystal lattice parameters of $\mathrm{Fe}_{2}(\mathrm{~B}, \mathrm{C})$ and $\mathrm{Fe}(\mathrm{B}, \mathrm{C})$ phases in $\mathrm{Fe}-10.1 \% \mathrm{~B}-\mathrm{C}$ alloy

\begin{tabular}{|c|c|c|c|c|c|c|c|}
\hline \multirow{2}{*}{$\begin{array}{l}\text { Carbon } \\
\text { content }\end{array}$} & \multirow{2}{*}{$\begin{array}{l}\text { Cooling rate, } \\
\mathrm{K} / \mathrm{s}\end{array}$} & \multicolumn{3}{|c|}{$\mathrm{Fe}_{2} \mathrm{~B}$ (tetragonal lattice) } & \multicolumn{3}{|c|}{ FeB (rhombic lattice) } \\
\hline & & $\mathrm{a}, \AA$ & $\mathrm{c}, \AA$ & $\mathrm{c} / \mathrm{a}$ & $\mathrm{a}, \AA$ & $\mathrm{b}, \AA$ & $\mathrm{c}, \AA$ \\
\hline \multirow{2}{*}{0.1} & 10 & $\begin{array}{c}5.1112 \pm \\
0.0031\end{array}$ & $\begin{array}{c}4.2442 \pm \\
0.0075\end{array}$ & 0.8304 & $\begin{array}{c}5.5057 \pm \\
0.0023\end{array}$ & $\begin{array}{c}4.0614 \pm \\
0.0096\end{array}$ & $\begin{array}{c}2.9517 \pm \\
0.0042\end{array}$ \\
\hline & $10^{3}$ & $\begin{array}{c}5.1109 \pm \\
0.0038 \\
\end{array}$ & $\begin{array}{c}4.2495 \pm \\
0.001 \\
\end{array}$ & 0.8315 & $\begin{array}{c}5.5041 \pm \\
0.0052 \\
\end{array}$ & $\begin{array}{c}4.0596 \pm \\
0.0106\end{array}$ & $\begin{array}{c}2.9501 \pm \\
0.0037\end{array}$ \\
\hline \multirow{2}{*}{0.7} & 10 & $\begin{array}{c}5.1141 \pm \\
0.0040\end{array}$ & $\begin{array}{c}4.2241 \pm \\
0.0137\end{array}$ & 0.8250 & $\begin{array}{c}5.4803 \pm \\
0.0115\end{array}$ & $\begin{array}{c}4.0401 \pm \\
0.0051\end{array}$ & $\begin{array}{c}2.9579 \pm \\
0.0055\end{array}$ \\
\hline & $10^{3}$ & $\begin{array}{c}5.1121 \pm \\
0.0020\end{array}$ & $\begin{array}{c}4.2393 \pm \\
0.0055\end{array}$ & 0.8293 & $\begin{array}{c}5.4778 \pm \\
0.0031\end{array}$ & $\begin{array}{c}4.0362 \pm \\
0.0021\end{array}$ & $\begin{array}{c}2.9595 \pm \\
0.0012\end{array}$ \\
\hline \multirow{2}{*}{1.6} & 10 & $\begin{array}{c}5.1149 \pm \\
0.0019\end{array}$ & $\begin{array}{c}4.2245 \pm \\
0.0120\end{array}$ & 0.8259 & $\begin{array}{c}5.4805 \pm \\
0.0018\end{array}$ & $\begin{array}{c}4.0397 \pm \\
0.0011\end{array}$ & $\begin{array}{c}2.9582 \pm \\
0.0007\end{array}$ \\
\hline & $10^{3}$ & $\begin{array}{c}5.1132 \pm \\
0.0031\end{array}$ & $\begin{array}{c}4.2356 \pm \\
0.0059\end{array}$ & 0.8284 & $\begin{array}{c}5.4737 \pm \\
0.0046\end{array}$ & $\begin{array}{c}4.0345 \pm \\
0.0037\end{array}$ & $\begin{array}{c}2.9614 \pm \\
0.0016\end{array}$ \\
\hline
\end{tabular}

solidification technology. Besides, in many potential applications $\mathrm{Fe}-\mathrm{B}$ alloys can be directly in contact with a carbon-containing medium. Therefore, the purpose of the present work is to investigate the influence of carbon and cooling rate on structure formation of $\mathrm{Fe}-\mathrm{B}-\mathrm{C}$ alloys inside the $\mathrm{Fe}_{2} \mathrm{~B}-\mathrm{FeB}-\mathrm{C}$ compositional triangle.

\section{Experimental procedure}

The Fe-B-C alloys containing 9.0-16.0\% B, $0.001-1.7 \% \mathrm{C}, \mathrm{Fe}$ - the balance (in wt. \%) were prepared of high purity $(99.93 \%-99.99 \%)$ components and melted in alumina crucibles using Tamman furnace. The cooling rate of the alloys was $10-10^{3} \mathrm{~K} / \mathrm{s}$. The average chemical composition of the alloys was studied by atomic absorption spectroscopy method using Sprut $C E \Phi-01-M$ device. The local chemical composition of phases was determined by an energy dispersive (EDX) attachment linked to JSM-6491LV scanning electron microscope. The alloys were examined by light-optical microscope Neophot. Quantitative metallography was carried out with structural analyzer Epiquant. X-ray diffraction analysis was done to identify the existing phases in produced samples on an X-ray diffractometer ДРОН-УМ-1 with $\mathrm{CuK}_{\alpha}$ source. The phase transformations were investigated by means of differential thermal analysis (DTA). Cooling curves were recorded for each sample at a cooling rate of $5 \mathrm{~K} / \mathrm{min}$. The Vickers microhardness $\left(\mathrm{H}_{\mu}\right)$ was measured from at least 10 different indentations, and fracture toughness
$\left(\mathrm{K}_{1 \mathrm{C}}\right)$ was evaluated from the crack length at the corners of the Vickers microindentation using $\Pi M T-3$ device.

\section{Experimental results and discussion}

In compositional range of $9-16 \%$ of $\mathrm{B}, 0.001$ $1.7 \% \mathrm{C}, \mathrm{Fe}$ - balance, the majority of the structure of the $\mathrm{Fe}-\mathrm{B}-\mathrm{C}$ alloys comprise $\mathrm{Fe}(\mathrm{B}, \mathrm{C})$ and $\mathrm{Fe}_{2}(\mathrm{~B}, \mathrm{C})$ solid solutions (Table 1). The maximal carbon solubility in $\mathrm{Fe}_{2} \mathrm{~B}$ iron hemiboride measured by EDX is about $0.55 \%$. The $\mathrm{Fe}(\mathrm{B}, \mathrm{C})$ phase has been found to dissolve up to $0.41 \%$. With cooling rate increasing from 10 to $10^{3} \mathrm{~K} / \mathrm{s}$, the deviations of lattice parameters from etalon values for iron borides increase (Table 2). It may be related to increasing carbon solubility in these phases. Above a critical content of carbon in $\mathrm{FeB}$ and $\mathrm{Fe}_{2} \mathrm{~B}$ phases, free graphite appears in the alloys structure (Table 1).

Depending on carbon content in the investigated $\mathrm{Fe}-$ $\mathrm{B}-\mathrm{C}$ alloys, the following structural changes are revealed. In the structure of two-phase peritectic $\mathrm{Fe}-\mathrm{B}-\mathrm{C}$ alloys containing $0.001-.165 \% \mathrm{C}$ primary dendrites of $\mathrm{Fe}(\mathrm{B}, \mathrm{C})$ phase are observed in the background of $\mathrm{Fe}_{2}(\mathrm{~B}, \mathrm{C})$ solid solution formed by peritectic reaction $\mathrm{L}+\mathrm{Fe}(\mathrm{B}, \mathrm{C}) \rightarrow \mathrm{Fe}_{2}(\mathrm{~B}, \mathrm{C})$ (Table 1, Fig. 1). In the alloys with composition close to peritectic point, $\mathrm{Fe}_{2}(\mathrm{~B}, \mathrm{C})$ phase may also crystallize directly from the liquid due to a low content of primary $\mathrm{Fe}(\mathrm{B}, \mathrm{C})$ phase. DTA thermograms show that temperature of peritectic reaction lowers to 1653 - $1643 \mathrm{~K}$ when carbon is added (Fig. 2, a). The weak exothermic effect at $1398 \mathrm{~K}$ may be related to 

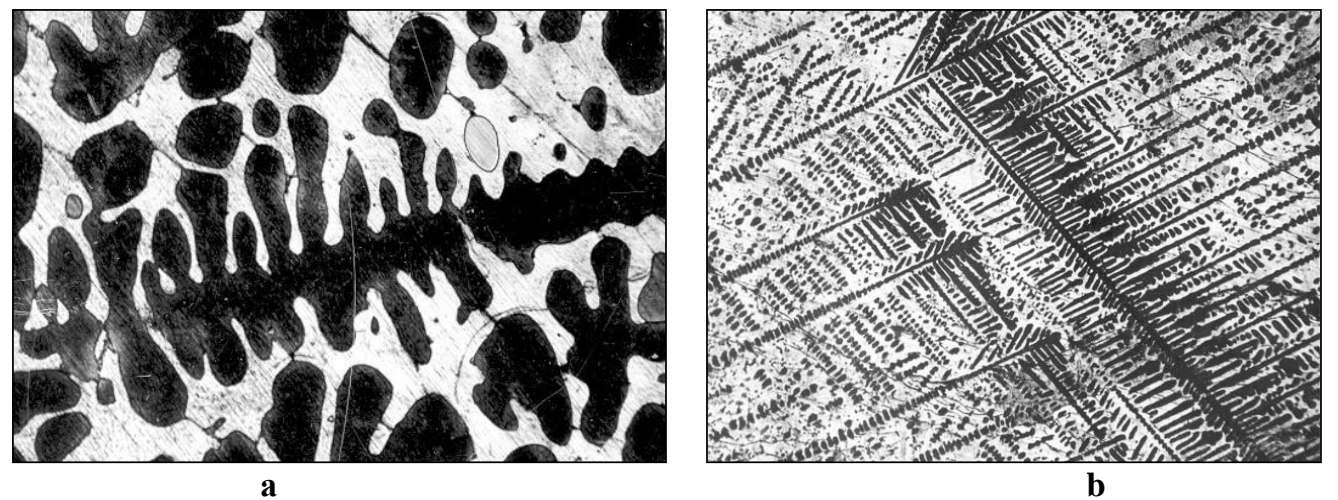

Fig. 1. Microstructure of $\mathrm{Fe}-12.1 \% \mathrm{~B}-0.1 \% \mathrm{C}$ alloy $(\mathrm{x} 300): \mathrm{a}-\mathrm{V}_{\text {cool }}=10 \mathrm{~K} / \mathrm{s} ; \mathrm{b}-\mathrm{V}_{\text {cool }}=10^{3} \mathrm{~K} / \mathrm{s}$

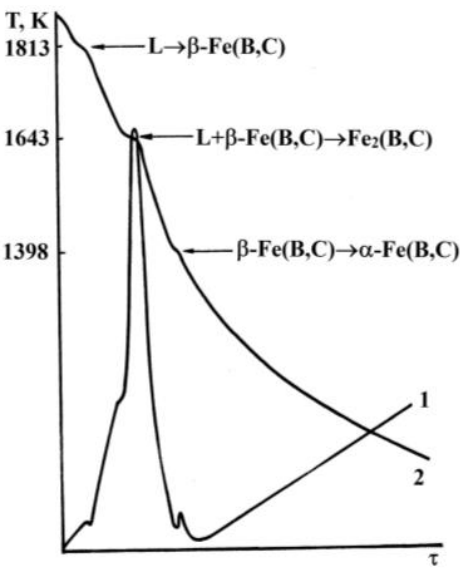

a

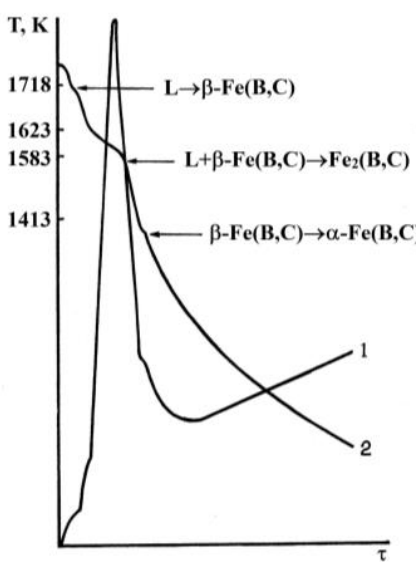

b

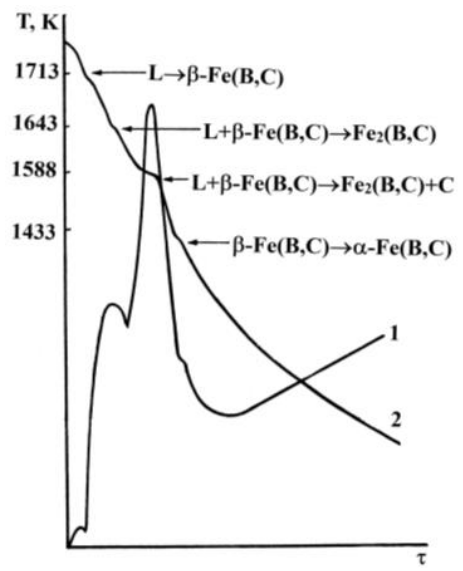

c

Fig. 2. Thermograms of $\mathrm{Fe}-12.1 \% \mathrm{~B}-0.1 \% \mathrm{C}(\mathrm{a}), \mathrm{Fe}-10.8 \% \mathrm{~B}-0.3 \% \mathrm{C}$ (b),

$\mathrm{Fe}-11.0 \% \mathrm{~B}-1.24 \% \mathrm{C}(\mathrm{c})$ alloys: $1-\Delta \mathrm{T}(\tau) ; 2-\mathrm{T}(\tau)$.

the polymorphic transformation $\beta-\mathrm{Fe}(\mathrm{B}, \mathrm{C}) \rightarrow \alpha-\mathrm{Fe}(\mathrm{B}, \mathrm{C})$ [4]. As the carbon content increases from $0.01 \%$ to $0.165 \%$, the relative amount of $\mathrm{Fe}(\mathrm{B}, \mathrm{C})$ phase increases by 10 vol. $\%$ on average which may be explained either by the facilitation of its nucleation or by the inhibition of the peritectic reaction.

Cooling rate during solidification does not affect the phase composition of two-phase peritectic alloys. With cooling rate increasing from 10 to $10^{3} \mathrm{~K} / \mathrm{s}$, the structural constituents tend to be fine (Fig. 1, b). A diameter $(d)$ of secondary dendritic arms of $\mathrm{Fe}(\mathrm{B}, \mathrm{C})$ crystals changes as a function of cooling rate $\left(\mathrm{V}_{\text {cool }}\right)$ as follows: $\ln d=-0.55 \cdot \ln \mathrm{V}_{\text {cool }}+3.0$. Carbon-containing $\mathrm{Fe}_{2} \mathrm{~B}$ - and FeB-based solid solutions solidified with a higher cooling rate do not practically exhibit changes in their crystal lattices parameters (Table 2). The volume fraction of $\mathrm{Fe}(\mathrm{B}, \mathrm{C})$ phase in the rapidly cooled alloys increases by 12 vol. $\%$ on average, and that of $\mathrm{Fe}_{2}(\mathrm{~B}, \mathrm{C})$ phase decreases correspondingly. The increase in both carbon content and cooling rate enhances the microhardness values.

As carbon content increases from 0.17 to $0.5 \%$, binary rod-like $\mathrm{Fe}_{2}(\mathrm{~B}, \mathrm{C})-\mathrm{Fe}(\mathrm{B}, \mathrm{C})$ eutectic additionally appears in the structure of two-phase peritectic-eutectic $\mathrm{Fe}-\mathrm{B}-\mathrm{C}$ alloys which can be attributed to the effect of $\mathrm{C}$ in the alloys during solidification (Table 1, Fig. 3,a) [14]. About formation of this eutectic also reported authors [15], but they did not explain mechanism of its crystallization in the alloys which structure should be peritectic according to the phase diagram.

The volume fraction of $\mathrm{Fe}_{2}(\mathrm{~B}, \mathrm{C})-\mathrm{Fe}(\mathrm{B}, \mathrm{C})$ eutectic decreases with increasing boron content in the alloys. Firstly, as the cooling rate increases over a range of 10 $700 \mathrm{~K} / \mathrm{s}$, the eutectic volumic amount increases and its constituents exhibit more fine morphology (Fig. 3,b). As the cooling rate is further raised up to $10^{3} \mathrm{~K} / \mathrm{c}$, the relative amount of the eutectic decreases. The microhardness of the eutectic increases from $17.5 \pm 0.2 \mathrm{GPa}$ to $19.0 \pm 0.5 \mathrm{GPa}$.

In the presence of carbon, binary $\mathrm{Fe}_{2}(\mathrm{~B}, \mathrm{C})-\mathrm{Fe}(\mathrm{B}, \mathrm{C})$ eutectic may appear in the $\mathrm{Fe}-\mathrm{B}-\mathrm{C}$ alloys due to a continuous transition of peritectic reaction $\mathrm{L}+\mathrm{Fe}(\mathrm{B}, \mathrm{C}) \rightarrow \mathrm{Fe}_{2}(\mathrm{~B}, \mathrm{C})$ into eutectic reaction $\mathrm{L} \rightarrow \mathrm{Fe}(\mathrm{B}, \mathrm{C})+\mathrm{Fe}_{2}(\mathrm{~B}, \mathrm{C})$ in a temperature range of $1623-1583 \mathrm{~K}$ (Fig. 2, b). Quenching microstructural analysis (stop-quenching) shows that at the temperatures of $1633-1623 \mathrm{~K}$ primary $\mathrm{Fe}(\mathrm{B}, \mathrm{C})$ crystals first dissolve in the peritectic reaction forming $\mathrm{Fe}_{2}(\mathrm{~B}, \mathrm{C})$ phase. Then, with boron and carbon accumulating in the liquid, the dissolution slows down and in the region of peritectic-toeutectic transition the interface of $\mathrm{Fe}(\mathrm{B}, \mathrm{C})$ dendrites stabilizes. Dissolution is terminated and in the presence of $\mathrm{Fe}(\mathrm{B}, \mathrm{C})$ phase $\mathrm{Fe}_{2}(\mathrm{~B}, \mathrm{C})$ crystals start forming in the liquid. The transition of the composition of the liquid into eutectic region is accompanied by its two-phase decomposition over a range of temperatures [16]. As a 


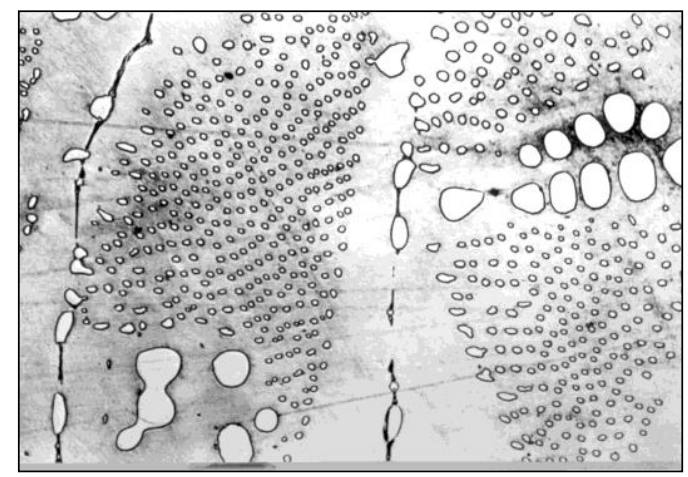

a

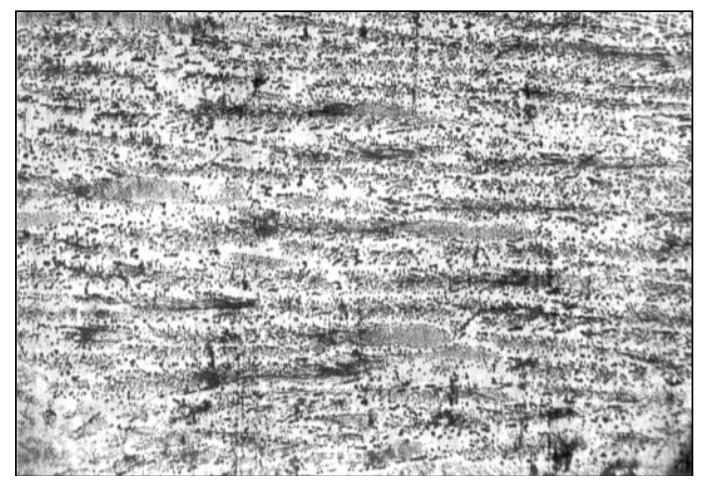

b

Fig. 3. Microstructure of $\mathrm{Fe}-10.8 \% \mathrm{~B}-0.3 \% \mathrm{C}$ alloy $(\mathrm{x} 300): \mathrm{a}-\mathrm{V}_{\text {cool }}=10 \mathrm{~K} / \mathrm{s} ; \mathrm{b}-\mathrm{V}_{\text {cool }}=700 \mathrm{~K} / \mathrm{s}$

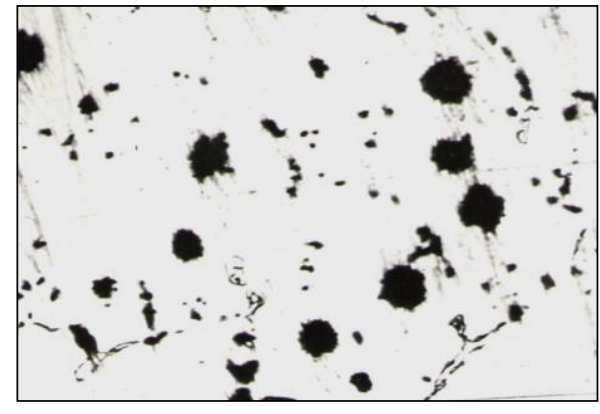

a

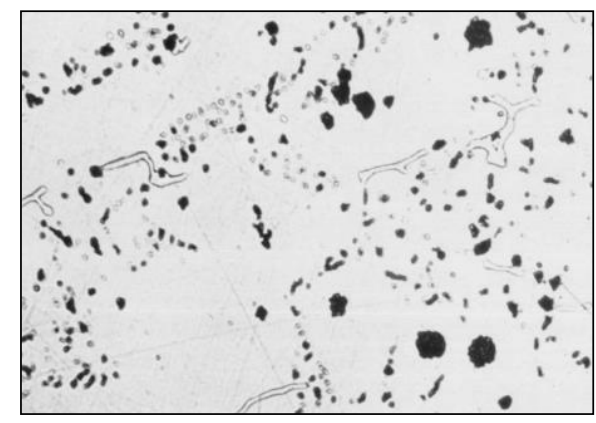

c

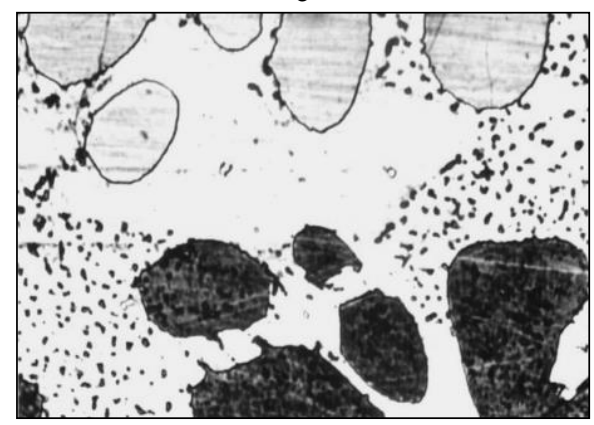

e

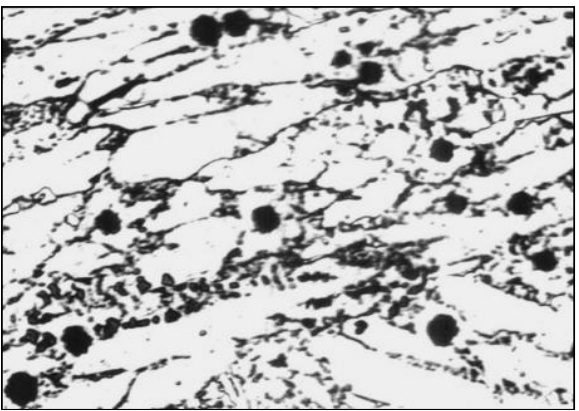

b

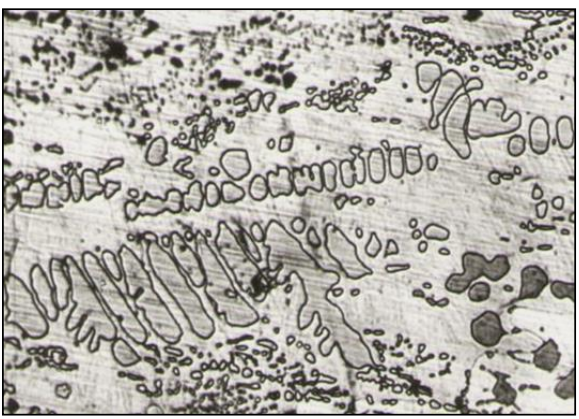

d

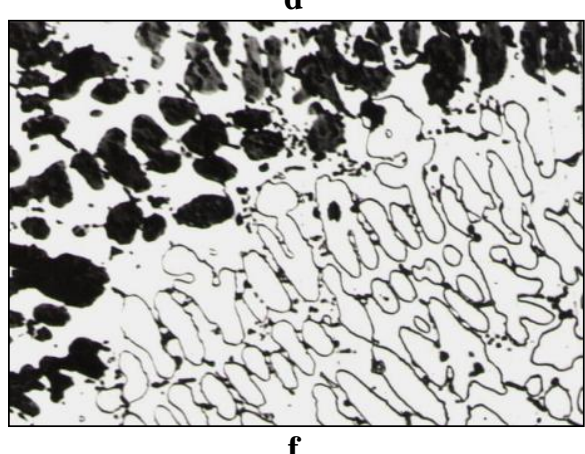

Fig. 4. Microstructure (x300) $\mathrm{Fe}-9.1 \% \mathrm{~B}-1.45 \% \mathrm{C}(\mathrm{a}, \mathrm{b}) ; \mathrm{Fe}-12.3 \% \mathrm{~B}-0.82 \% \mathrm{C}(\mathrm{c}, \mathrm{d})$; $\mathrm{Fe}-14.3 \% \mathrm{~B}-0.8 \% \mathrm{C}(\mathrm{e}, \mathrm{f})$ alloys: $\mathrm{a}, \mathrm{c}, \mathrm{e}-\mathrm{V}_{\text {cool }}=10 \mathrm{~K} / \mathrm{s} ; \mathrm{b}, \mathrm{d}, \mathrm{f}-\mathrm{V}_{\text {cool }}=10^{3} \mathrm{~K} / \mathrm{s}$.

result, in the structure of ternary $\mathrm{Fe}-\mathrm{B}-\mathrm{C}$ alloys containing $9.0-16.0 \% \mathrm{~B}$ and $0.17-0.5 \% \mathrm{C}$, univariant $\mathrm{Fe}_{2}(\mathrm{~B}, \mathrm{C})-\mathrm{Fe}(\mathrm{B}, \mathrm{C})$ eutectic is observed. So, the formation of the eutectic is strongly influenced by the addition of carbon.

When the carbon concentration is further increased up to $0.5-1.7 \%$, the structure of three-phase peritecticeutectic $\mathrm{Fe}-\mathrm{B}-\mathrm{C}$ alloys features the formation of structural constituents composed of graphite (Table 1, Fig. 4). Globular graphite inclusions are usually observed in the alloys containing 9.0-9.2\% B (Fig. 4,a). Besides, in the overall concentration range, two-phase $\mathrm{Fe}_{2}(\mathrm{~B}, \mathrm{C})-\mathrm{C}$ colonies are revealed at $\mathrm{Fe}_{2}(\mathrm{~B}, \mathrm{C}$ ) boundaries (Fig. 4, 2,c). They exhibit globular dispersed morphology. Their formation is related to four-phase peritectic transformation $\mathrm{L}+\mathrm{Fe}(\mathrm{B}, \mathrm{C}) \rightarrow \mathrm{Fe}_{2}(\mathrm{~B}, \mathrm{C})+\mathrm{C} \quad$ [12]. As cooling rate is raised up to $10^{3} \mathrm{~K} / \mathrm{s}$, the microstructural size and relative amount of this structural constituent decrease (Fig. 4, b, d, f). With boron concentration increasing above $12.0 \%$, the amount of globular graphite 
inclusions decreases and ternary $\mathrm{Fe}_{2}(\mathrm{~B}, \mathrm{C})-\mathrm{Fe}(\mathrm{B}, \mathrm{C})-\mathrm{C}$ eutectic appears at $\mathrm{Fe}_{2}(\mathrm{~B}, \mathrm{C})$ boundaries (Fig. 4,c). Its eutectic origin may be concluded from the results of quenching microstructural analysis. The ternary eutectic is not revealed in the $\mathrm{Fe}-\mathrm{B}-\mathrm{C}$ alloys with boron content ranging from 14 to $16 \% \mathrm{~B}$ (Fig. 4,e). The increase in cooling rate up to $10^{3} \mathrm{~K} / \mathrm{c}$ induces refinement of the structure and decrease in the volume fraction of eutectic constituents (Fig. 4, b, d, f). Wherein, a total microhardness of the alloys increases by $15 \%$ on average, and fracture toughness - by 2.5 times.

The formation of the ternary $\mathrm{Fe}_{2}(\mathrm{~B}, \mathrm{C})-\mathrm{Fe}(\mathrm{B}, \mathrm{C})-\mathrm{C}$ eutectic in the structure of three-phase peritectic-eutectic $\mathrm{Fe}-\mathrm{B}-\mathrm{C}$ alloys may be explained as follows. It is known that figurative point of the four-phase peritectic transformation $\mathrm{L}+\mathrm{Fe}(\mathrm{B}, \mathrm{C}) \rightarrow \mathrm{Fe}_{2}(\mathrm{~B}, \mathrm{C})+\mathrm{C}$ is the point in which intersect three univariant curves that correspond to two eutectic transformations $\mathrm{L} \rightarrow \mathrm{Fe}_{2}(\mathrm{~B}, \mathrm{C})+\mathrm{C}$, $\mathrm{L} \rightarrow \mathrm{Fe}(\mathrm{B}, \mathrm{C})+\mathrm{C}$ and one peritectic transformation $\mathrm{L}+\mathrm{Fe}(\mathrm{B}, \mathrm{C}) \rightarrow \mathrm{Fe}_{2}(\mathrm{~B}, \mathrm{C})$. However, considering the possibility of continuous transition of three-phase peritectic transformation $\mathrm{L}+\mathrm{Fe}(\mathrm{B}, \mathrm{C}) \rightarrow \mathrm{Fe}_{2}(\mathrm{~B}, \mathrm{C})$ into three-phase eutectic transformation $\mathrm{L} \rightarrow \mathrm{Fe}(\mathrm{B}, \mathrm{C})+\mathrm{Fe}_{2}(\mathrm{~B}, \mathrm{C})$, the decomposition of the liquid by reaction $\mathrm{L} \rightarrow \mathrm{Fe}_{2}(\mathrm{~B}, \mathrm{C})+\mathrm{Fe}(\mathrm{B}, \mathrm{C})+\mathrm{C}$ at $1588 \mathrm{~K}$ is possible when the composition of the alloy falls within the four-phase eutectic region of the phase diagram [16].

\section{Conclusions}

Depending on carbon content, the $\mathrm{Fe}-\mathrm{B}-\mathrm{C}$ alloys in the compositional range of $9.0-16.0 \% \mathrm{~B}, 0.001-1.7 \%$ $\mathrm{C}, \mathrm{Fe}-$ balance cooled at rates from 10 to $10^{3} \mathrm{~K} / \mathrm{s}$, exhibit two-phase peritectic $(0.001-0.165 \% \mathrm{C})$, twophase peritectic-eutectic $(0.17-0.5 \% \mathrm{C})$ and three-phase peritectic-eutectic $(0.55-1.7 \% \mathrm{C})$ structures.

The two-phase peritectic alloys have been found to consist of primary $\mathrm{Fe}(\mathrm{B}, \mathrm{C})$ crystals and $\mathrm{Fe}_{2}(\mathrm{~B}, \mathrm{C})$ phase forming in two ways: through the ternary peritectic reaction or directly from the melt. As cooling rate increases up to $10^{3} \mathrm{~K} / \mathrm{s}$, the resultant microstructural size and volume fraction of primary $\mathrm{Fe}(\mathrm{B}, \mathrm{C})$ phase decrease, microhardness and fracture toughness increase.

The two-phase peritectic-eutectic alloys feature the formation of rod-like $\mathrm{Fe}_{2}(\mathrm{~B}, \mathrm{C})-\mathrm{Fe}(\mathrm{B}, \mathrm{C})$ eutectic in addition to $\mathrm{Fe}(\mathrm{B}, \mathrm{C})$ and $\mathrm{Fe}_{2}(\mathrm{~B}, \mathrm{C})$ phases. The eutectic appears in the $\mathrm{Fe}-\mathrm{B}-\mathrm{C}$ alloys due to a continuous transition of univariant peritectic transformation $\mathrm{L}+\mathrm{Fe}(\mathrm{B}, \mathrm{C}) \rightarrow \mathrm{Fe}_{2}(\mathrm{~B}, \mathrm{C})$ into eutectic transformation $\mathrm{L} \rightarrow \mathrm{Fe}(\mathrm{B}, \mathrm{C})+\mathrm{Fe}_{2}(\mathrm{~B}, \mathrm{C})$ in a temperature range of $1623-1583$ K. First, with cooling rate increasing from 10 to $700 \mathrm{~K} / \mathrm{s}$, a volume fraction of the eutectic increases. The further increase in a cooling rate up to $10^{3} \mathrm{~K} / \mathrm{s}$ gives rise to the decrease in a relative amount of the eutectic. Wherein, microhardness of the eutectic increases.

In the three-phase peritectic-eutectic alloys, the following structural constituents are present: $\mathrm{Fe}_{2}(\mathrm{~B}, \mathrm{C})$ and $\mathrm{Fe}(\mathrm{B}, \mathrm{C})$ solid solutions, graphite, $\mathrm{Fe}_{2}(\mathrm{~B}, \mathrm{C})-\mathrm{C}$ colonies and ternary $\mathrm{Fe}_{2}(\mathrm{~B}, \mathrm{C})-\mathrm{Fe}(\mathrm{B}, \mathrm{C})-\mathrm{C}$ eutectic. Globular graphite inclusions and $\mathrm{Fe}_{2}(\mathrm{~B}, \mathrm{C})-\mathrm{C}$ colonies form in the four-phase peritectic transformation $\mathrm{L}+\mathrm{Fe}(\mathrm{B}, \mathrm{C}) \rightarrow \mathrm{Fe}_{2}(\mathrm{~B}, \mathrm{C})+\mathrm{C}$. The ternary $\mathrm{Fe}_{2}(\mathrm{~B}, \mathrm{C})-$ $\mathrm{Fe}(\mathrm{B}, \mathrm{C})-\mathrm{C}$ eutectic crystallizes during the four-phase eutectic transformation $\mathrm{L} \rightarrow \mathrm{Fe}_{2}(\mathrm{~B}, \mathrm{C})+\mathrm{Fe}(\mathrm{B}, \mathrm{C})+\mathrm{C}$ that undergoes instead of the peritectic transformation $\mathrm{L}+\mathrm{Fe}(\mathrm{B}, \mathrm{C}) \rightarrow \mathrm{Fe}_{2}(\mathrm{~B}, \mathrm{C})+\mathrm{C}$ due to the continuous transition of the univariant peritectic transformation $\mathrm{L}+\mathrm{Fe}(\mathrm{B}, \mathrm{C}) \rightarrow \mathrm{Fe}_{2}(\mathrm{~B}, \mathrm{C})$ into the eutectic transformation $\mathrm{L} \rightarrow \mathrm{Fe}(\mathrm{B}, \mathrm{C})+\mathrm{Fe}_{2}(\mathrm{~B}, \mathrm{C})$ in a narrow temperature range. As a cooling rate increases from 10 to $10^{3} \mathrm{~K} / \mathrm{s}$, the refinement of eutectic constituents and decrease in their amount are observed. Rapidly cooled alloys exhibit enhanced total microhardness and fracture toughness.

Sukhova O.V. - Professor, Doctor of Science
(Engineering), Professor of the Department of
Experimental Physics.

[1] X. Ren, H. Fu, J. Xing, Y. Yang, S. Tang, Journal of Materials Research 32(16), 1 (2017).

[2] I.M. Spiridonova, E.V. Sukhovaya, V.F. Butenko, A.P. Zhudra, A.I. Litvinenko, A.I. Belyi, Powder Metallurgy and Metal Ceramics 32(2), 139 (1993).

[3] O. Hesse, J. Merker, M.N. Brykov, V.G. Efremenko, Tribologie und Schmierungstechnik 60(6), 37(2013).

[4] I.M. Spiridonova, E.V. Sukhovaya, V.P. Balakin, Metallurgia 35(2), 65 (1996).

[5] O.V. Sukhova, Metallofizika i Noveishie Tekhnologii 31(7), 1001 (2009).

[6] I.M. Spiridonova, O.V. Sukhova, A.P. Vashchenko, Metallofizika i Noveishie Tekhnologii 21(2), 122 (1999).

[7] O.V. Sukhova, Y.V. Syrovatko, Metallofizika i Noveishie Tekhnologii 33 (Special Issue), 371 (2011).

[8] E.V. Sukhovaya, Journal of Superhard Materials 35(5), 277 (2013).

[9] K.I. Portnoi, V.M. Romashov, Powder Metallurgy and Metal Ceramics 5, 48 (1972).

[10] E. Kneller, Y. Khan, Z. Metallkunde 78(12), 825 (1987).

[11] I.M. Spyrydonova, Metallovedenie i Termicheskaya Obrabotka Metallov i Splavov 2, 58 (1984).

[12] E. Schurmann, L. Shao-Xiong, Giessereiforschung 37(4), 121 (1985).

[13] V. Homolova, L. Ciripova, A. Vyrostkova, J. Phase Equilibria and Diffusion 36(6), 599 (2015).

[14] I.M. Spyrydonova, E.V. Sukhovaya, G.A. Sergeyev, Theory and Practice of Metallurgy 4-5, 57 (2006).

[15] N.Y. Filonenko, E.Y. Beryoza, O.G. Bezrukavaya, Physics and Chemistry of Solid State 5, 168 (2013).

[16] D.A. Petrov, Binary and Ternary Systems (Metallurgy, Moscow, 1986). 


\section{O.В. Сухова}

\section{Вплив вмісту вуглецю та швидкості охолодження на структуру високобористих сплавів Fe-B-C}

Дніпровський національний університет імені Олеся Гончара, Дніпро, Україна, sukhovaуa@ukr.net

У роботі досліджено структурний та фазовий склад високобористих сплавів $\mathrm{Fe}-\mathrm{B}-\mathrm{C}$ в області концентрацій 9,0 - 16,0\% В, 0,001 - 1,7 \% C, $\mathrm{Fe}$ - залишок (у мас. \%). Швидкість охолодження сплавів становила $10-10^{3} \mathrm{~K} / \mathrm{c}$. Використано методи кількісного металографічного, рентгеноструктурного, мікрорентгеноспектрального і диференціального термічного аналізів. Встановлено, що максимальна розчинність вуглецю в гемібориді $\mathrm{Fe}_{2} \mathrm{~B}$ становить $0,55 \%$, а в монобориді $\mathrm{FeB}-0,41 \%$. Залежно від структури можна виділити сплави, що належать до двофазної перитектичної $\left(\mathrm{Fe}_{2}(\mathrm{~B}, \mathrm{C})+\mathrm{Fe}(\mathrm{B}, \mathrm{C})\right.$ ), двофазної перитектико-евтектичної $\left(\mathrm{Fe}_{2}(\mathrm{~B}, \mathrm{C})+\mathrm{Fe}(\mathrm{B}, \mathrm{C})\right)$ та трифазної перитектико-евтектичної $\left(\mathrm{Fe}_{2}(\mathrm{~B}, \mathrm{C})+\mathrm{Fe}(\mathrm{B}, \mathrm{C})+\mathrm{C}\right)$ областей діаграми стану $\mathrm{Fe}-\mathrm{B}-\mathrm{C}$. Появу евтектичних складових у структурі досліджених сплавів пояснено переходом перитектичної реакції $\mathrm{L}+\mathrm{Fe}(\mathrm{B}, \mathrm{C}) \rightarrow \mathrm{Fe}_{2}(\mathrm{~B}, \mathrm{C})$ в евтектичну реакцію $\mathrm{L} \rightarrow \mathrm{Fe}(\mathrm{B}, \mathrm{C})+\mathrm{Fe}_{2}(\mathrm{~B}, \mathrm{C})$ в інтервалі температур 1623 - 1583 К у присутності вуглецю. Збільшення швидкості охолодження 310 до $10^{3} \mathrm{~K} / \mathrm{c}$ супроводжується подрібненням структурних складових, зміною їх об'ємного вмісту, збільшенням мікротвердості та коефіцієнта тріщиностійкості.

Ключові слова: структура, швидкість охолодження, кристалізація, фазові перетворення, мікромеханічні характеристики. 